Mintfundia In Agrarian Reform:

A Colombian Example

\author{
by: \\ Dale W.Adams \\ and \\ Sam Schulman
}

September 1966

Department of Agricultural Economics and Rural Sociology

The Ohio State University 


\section{Minifundia In Agrarian Reform: A Colombian Example*}

\section{By}

\section{Dale W Adams and Sam Schulman \\ The Ohio State University \\ Colorado State University}

Some of the most vexing problems faced by Agrarian Reform Agencies in Latin America are those associated with small farm units (minifundia). Agrarian reform programs initiated in these countries have placed heavy emphasis on the correction of these problems, and many of the agrarian reformers have attempted to do this by drawing from the European experience with minifundia. - In almost every case, however, the methods applied to the European problems have proven inadequate in Latin America. As a result of this, most Agrarian Reform Agencies are now directing their efforts away from minifundia.

We suggest in the following discussion that efforts to remedy minifundia problems have been frustrated partialiy because of the heterogeneity of the small farm units found in Latin America; the term minifundia covers a number of distinct types of units whose characteristics, problems, and possibilities for solution are very different. Moreover, many of the minifundia in Latin America differ substantially from those found in Europe. On the basis of several functional characteristics, we go on to suggest a typology for classifying minifundia in Latin America so that remedial alternatives can be more easily identified. From this classification we select one type, the dependent, for further discussion. By the use of a Colombian example, we describe the socio-economic characteristics of several prominent forms of dependent minifundia, and relate these characteristics to some of the remedial alternatives.

\section{Types of Minifundia}

In a broad sense the term minifundia has been used in Latin America to describe small farms which are often inadequate to meet the lifesustaining needs of the families who exploit them. Generically, small farms with less than three to five hectares of land are usually classified as minifundia. $2 /$ Large numbers of these types of units can be encountered in almost every part of Latin America. In Colombia, for example, over one-half 
of all the farm units have less than three hectares of land. 3 / A number of these minifundia concentrations are located close to urban centers, but others are quite isolated. In some instances the minifundia essentially function as production units, while others are mainly places of residence. Occupants of minifundia may be highly dependent on income earned from labor on nearby large landholdings; others are employed in urban areas or engaged in some type of home industry. In a few areas these small farm units are made up by a number of fragmented parcels, in others they contain only one or two lots. The decay of the indigenous communal systems in some areas has left heavy concentrations of minifundia whose occupants are closely tied to tradition. Other minifundia famllies have close contact with urban centers, adopt change rapidly, and are less tied to their land. There is also a wide range of tenure arrangements among these small farm operators. Some own the land in fee simple, others have mixed tenure systems, others have a group title or no title, and still others operate the land as tenants. There is, therefore, not a single minifundia problem, but rather a complex of problems which varies widely from case to case.

In Colombia it is useful to identify three general types of minifundia on the basis of the following criteria: (1) the basic motivation involved in the operation of the unit, (2) the relation of production decisions to the market, and (3) the over-all occupational structure of the family which occupies the unit. 4 / Using these criteria, the first type of small unit which can be identified is the independent minifundia. On these units, most of the family's labor supply is devoted to the direct exploitation of the small farm; production decisions are principally oriented $b$ direct consumption needs rather than market conditions. Large landholdings seldom affect the labor patterns associated with this type of minifundia, and off-farm employment is not an important factor. In Colombia, these small farm units tend to be concentrated in parts of the Departaments of Nariño, Boyaca and Cundinamarca.

The second type is the commercial minifundia. These units also absorb much of the family's labor supply, but most production decisions are closely tied to market conditions and not to direct consumption needs. Small units of this type are located throughout Colombia, but tend to be concentraced in the coffee regions, the tobacco areas, and in the margin around the large cities where truck garden farms are common. $\underline{6}$ In a few cases, 
especially with regard to truck gardens, income from farm production on these units may be relatively high.

The third type of minifundia is the dependent, and it is generally the most complex. These units are distinguished by the fact that a substantial part of the family's income is derived from off-unit employment; examples of these can be found throughout Colombia. The dependent minifundia is of special interest because of its complex characteristics, and the difficulties of applying remedial alternatives through agrarlan reform programs. It is often useful to sub-divide the dependent minifundia into at least three distinct sub-types. The first sub-type is made up of residence clusters around urban centers, and of people living in urban centers who operate small agricultural plots outside of town. These holdings are generically minifundia since they are small and located in rural areas. Functionally, however, the plots are principally places of residence for people employed in the urban center, or serve as garden plots for those living in town. The income generated from these parcels is generally only a small part of the operator's total earnings.

A second sub-type of the dependent minifundia is the small exploitations located nearby, or on, a large landholding. Typically, these units are somewhat removed from the large urban centers. The small units are usually farms, and occupants derive some of the family's necessities from the farm. The operators cannot, however, exist without income derived from work on the large fincas or haciendas. The occupant may or may not own the unit, and he is essentially a farm laborer on someone else's exploitation. II

The third sub-type is a mixed form of dependent minifundia. It embraces some of the characteristics of the two sub-types mentioned above. It is not adjacent to, but may be relatively near an urban center. It often includes definable areas of minifundia concentration where production for home consumption plus some commercial crops are grown. A majority of the Income for the occupants, nevertheless, comes from day labor on large holdings, from work in the urban centers, or artisinal activities in the village or in the home itself.

From a socio-economic point-of-view the dependent minifundia are probably the most provocative for study. In many cases they are numerically superior to the other two tppes. Also, they often represent both a form of residence and "making-a-living" in transition: displacing rural characteristics by those more nearly urban, or mixing the two in an often unhappy 
combination. The various sub-types of dependent minifundia also present difficulties for any orthodox program of resolving problems through an agrarian reform program. Although some areas contain mostly one sub-type of dependent minifundia, it is not uncommon to find all three sub-types in one area. Such an area is found around the village of Sopo, located in the Valley of the Teusaca River about 25 miles northeast of Bogota, Colombia. The minifundia found in this area illustrate the complexity of the problems faced, and also indicate the limitations associated with some of the most often discussed remedial approaches for minifundia.

Background on Sopo

How and why small farm units were formed are important factors in explaining the socio-economic characteristics of minifundia. Many of the problems which presently exist in the community of Sopo, for example, are deeply rooted in events which have taken place over the past four hundred years.

When the Spanish under Gonzalo Jimenez de Quesada conquered the Chibcha Indians in 1538, there were three small Indian villages located in the Sopo Valley. 9 / In short order, the Sopo Indians were organized into an encomidnda, and one of the soldiers of Jimenez de Quesada was placed in charge. $\frac{10 /}{}$ Fragmentary evidence suggests that about 400 Indians inhabited the area at this time. Most of the land in the flat part of the valley was soon given to the conquerors in the form of land grants, and the Indians were squeezed to the sides of the valley. With the Indian labor furnished through the encomiendas these large land grants were exploited and gradually expanded. Sometime before 1600 the areas on which the Indians settled were recognized as reserves whose lands belonged to the Indians.

By the time of Independence in 1819, much of the good land in Sopo was owned by a Spanish priest who fled after the Spaniards were defeated. His hacienda was given intact to General Erancisco de Paula Santander, a later president of the country, for services rendered during the fight for Independence. $11 /$ From the period of Independence to 1938 the population of Sopo was stable at about 2,500 inhabitants. There was, however, a substantial amount of sub-division of the large landholdings during this period. In 1935 there were some 34 major haciendas located in the valley, and most of these were owned by people living at least part of the time in Bogota. 12 / 
Most of the 438 rural families enumerated in the 1938 Population Census were working on these large landholdings, and/or worked their small holdings along the edge of the valley. Cereals, corn, and livestock were the principal enterprises on the large units; wheat, potatoes, corn, and broadbeans (habas) were the major crops on the small units.

In several respects, sharp changes have taken place in sopo over the past thirty years. The population, for example, has sharply increased from 2,700 in 1938 to 4,200 in 1964. About 85 percent of this population growtin has taken place since 1951. There has been an addition of about 300 residents who live in the small village, and an increase of about 1,200 rural residents during the 1938 to 1964 period. $13 /$ Many of the latter have settled down as tenant-workers on the large haciendas in the valley. The development of some light industry in the town such as a milk processing plant partially explains the urban growth. The increase in the rural population has been due to some immigration due to violence in other areas, and to the intensification in the utilization of the agricultural lands which has required more hand labor.

About one-third of the flat agricultural land in Sopo has been placed into mechanized production of wheat and barley. Over 60 tractors were being used in 1960 in this regard. Much of the remaining flat land supported more than 6,000 head of cattle, many of which are improved dairy breeds. $14 /$ The proximity of Bogota, plus the nearby milk processing plant provide a growing market for Sopo's dairy products.

Other conditions in Sopo have changed less or not at all. As can be noted in Table 1, of the 34 haciendas found in the valley in 1935, twentynine of these still had more than 100 hectares of land in 1964. The remaining five had been substantially fractionated during this period. Although there has been some shrinking in the size of the other large units over the past 30 years, about one-half of the farm land in the valley and along the sides of the hills was held in units of 100 hectares or more. It can also be noted in Table 1 that 176 of the 729 rural property owners in Sopo lived outside of the valley, mostly in Bogota. These absentee owners hold title to over two-thirds of the land in the valley, and to about 75 percent of the flat fertile part. Concrete historical information is lacking, but one gets the impression that, in spite of a substantial reduction in the size dimension of the holdings in Sopo, there has been relatively little change in the proportion of land owned by absentee owners 
over the years. Large landholdings which have been divided through inheritance or commercial sale have gone into hands of relativas. or individuals who live outside the valley.

The Dependent Minifundia in Sopo

As can be noted in Table 1 there are about 450 rural landholdings in Sopo which total five hectares or less. About eighty of the owners of these live outside of the valley, and a few of the remaining rent their lands to larger operators. There are, then, approximately three hundred owneroperators of minifundia units in Sopo. In addition, however, there are about 150 families who live and work on the larger units, and who have use-rights to small parcels of land within the haciendas. Countine these, a total of about 450 minifundia units can be identified in Sopo.

As mentioned earlier, for a general classification we have called these minifundia in Sopo the dependent type because of the importance of off-unit occupations among the operators. Only a handful of small farm operators in the area have intensive truck garden farms that can be identified as commercial minifundia. Almost none of the independent type minifundia units are present in the area. A series of detailed studies in the valley showed that all three sub-types of dependent minifundia discussed above can be identified in Sopo.

The mixed dependent minifundia

The most easily identifled group of small farm units in Sopo are the approximately 200 units with houses which are located on the sides of the valley, mainly in two zones, which once made up the Indian reservations. About one-half of the families living in these two areas depend on agricultural production, and/or work on other farms for their principal means of livelihood. Another one-quarter of the families are dependent on some sort of craftsman work for their main source of income. The remaining onequarter are employed in the local village or other urban centers. In a few cases, elderly parents live in these minifundia areas but rely upon income furnished by their grown children to maintain themselves.

As could be expected from first impressions, about eighty percent of the families living in these areas were operating less than three hectares of land. Most of these had only one parcel. Of the remaining twenty percent, 
however, several had over twenty hectares of land which included up to four parcels. Only about 15 percent of the small farm units included nonowner operated lands. Share rentals and special family arrangements made up most of these relationships.

Except for the few residents in these minifundia areas who operated relatively large units, the minifundia only provided a small portion of the family's income. Only six of these small units produced sales of more than 50 dollars worth of products during 1964. Wheat and corn were the principal commodities sold. Most of the producers of wheat were using commercial fertilizers and improved varieties of wheat. A handful of these small units had cattle, and only about one-third had several head of sheep. Few of these families could borrow more than the equivalent of one hundred dollars per year for production credit, and less than twenty percent, mostly the larger farm operator, made regular use of any kind of production credit. Over forty percent of the operators of these small units were over 50 years of age. It appears that the out-migration process has been age, education, and health selective; many of the young, healthy, and fairly well educated people have left these families for Bogota.

The minifundia associated with the urban areas.

There are about 100 families that live in the village of Sopo or on the outskirts of town who own small plots of land in the rural area. This is about one-third of the families living in the village. A few additional operators of large units also live in the village. Most of the holders of small plots own less than two hectares of land made up of one or two parcels. A wide diversity of principal occupations was found among these owners. Almost all of the small landowners who lived in the town had major sources of income outside of their exploitation. Many ran small shops, worked in public office, or acted as middlemen for agricultural commodities. Still others had sma1l home industries, and a few depended on employment in the rural area for supplemental income.

In some respects the urban residents in Sopo who operate small farms resemble the large absentee landowners who own land in Sopo but live in Bogota. That is, they only spend a small portion of their time making decisions about the farm exploitation, and their principal interests are focused on other economic activities. A number of these farm owners had inherited their small parcels after they were vell established in other 
occupations. Still others purchased the small plots with savings in order to have a more secure investment.

Minifundia associated with large units

As mentioned earlier, there are about 150 families who live and work on the large commercial farms in the flat part of the valley. As part of their wages many of these families are given a small plot with about one hectare of land for subsistence crops, and a home. Some of the largest haciendas in the valley have up to fifteen families living on the farm. One of the workers is usually the mayordomo who makes the day-to-day decisions. On the units which have tractors and trucks, several of the workers are occupied as drivers. The rest of the workers are used as unskilled labor in planting, harvesting, milking, and general upkeep of the farm.

Except for the drivers and the meyordomo the salaries for these workers averaged about one dollar per day in 1964. In some cases where a dairy herd occupied the farm, the workers were also given a few dairy products regularly. The mayordomo and drivers were generally paid about twice the amount given to the common laborers. In a few cases the mayordomos were also allowed to have a couple of cattle on their small parcel, but in general the common workers had no more than several head of chickens.

Very few of the workers had more than two years of formal education. A number of them had moved into sopo from other areas in order to obtain employment. A few of them were sons of landless families or small farm operators who lived along the sides of the valley, but who could not find employment opportunities in urban areas. With few exceptions the occupants of these small units had spent their entire adult lives as agricultural laborers. Because almost all of the production on their small parcels of land was for home consumption, they had little or no experience with making decisions about commercial agicultural production. Furthermore, the occupants of these small units $\varepsilon \in 1$ r.om owned any kind of farming tools; they were completely dependent upon the large landowner for these implements.

In many respects Colombia has a rather complete labor code which is aimed at regulating the working conditions for these farm laborers. This includes a minimum wage, severance pay based on length of service, annual 
vacation and bonuses, extra pay for work done on holidays and Sundays, and medical benefits. In most cases the permanent workers on the large commercial farms in Sopo would be eligible for these benefits. Aside from occasional gratuities given to these workers in Sopo by the large landowners, however, few of the elements of the labor law were being fulfilled. There was an almost total ignorance, on the part of the workers in the Sopo area, of their rights under the law. Moreoever, those who knew about some elements of the law rore afraid to demand their rights because dismissal might follow.

\section{Possstilities for Remedial Techniques}

As we heve nointed out in the nrevious discuscinn, there are a number of inportant diffemoss song the minipndja miss in sopo. These include varistion in rotivation for oserating the srali wat, sources of income, levei nf education and age of the oresters, breadth of farming experience, and antecetents through with the swll whiss wore fomed. Low levels of incoria and lask of vertical mobixty, however, are characteristics common among the operators of those unis. As might be expected, the heterogeneous

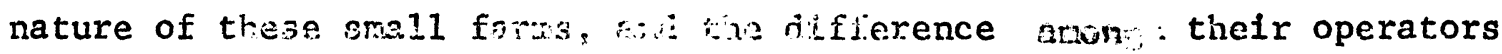
seriously affacts the soope ari gphitsobility of the various remediel technigias wich might be Eritin?.

With respect to the use of parcel consolidation in Sopo, it is doubtful that more than a handful of farm units in the area could benefit through combining several. scatiseac pricels. 15! Although a few of the units in the

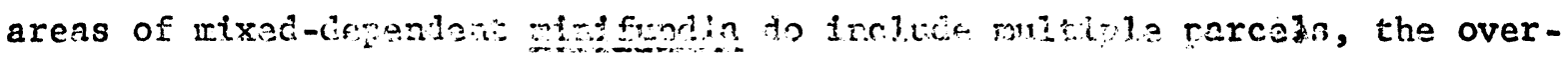

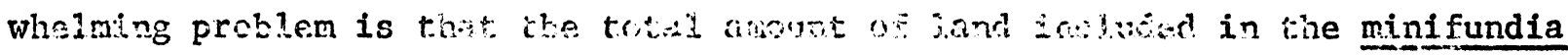
doer not add up to visis wits, ant chere se litita thit poreal consolidation can din to rasedy this itustion.

Other acrstian rosorm alternatives such as superrised credit and the

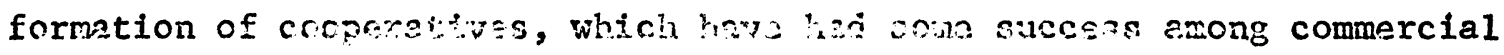

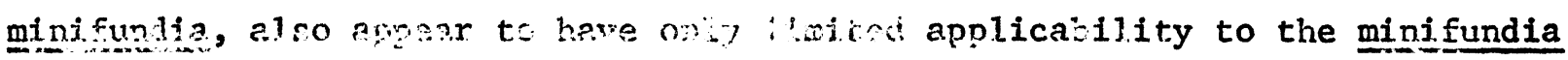

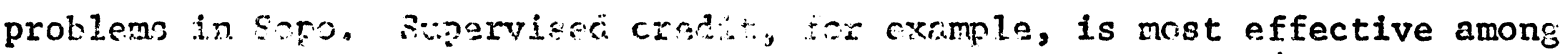

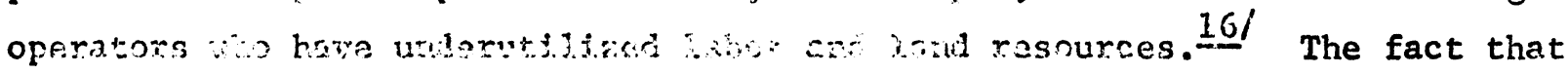

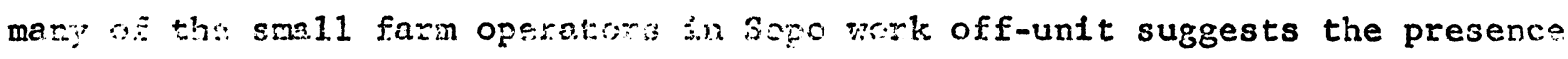
of exreass labor for on-farm vrokk. Fers of these small units, however, have sufficient land to make a viable farm unit even with additional doses of credit and supervision. Moreover, of the operators of these units, 
especially the tenant-workers on the large units, few have had managerial experience with farms which were organized to react to market conditions. An 1lliterate, fifty year old individual who has been a farm worker all his working life is not a good bet to become a successful operator of a commercial farm even with supervision and credit.

Likewise, marketing cooperatives have limited possibilities because the operators of these dependent minifundia, unlike operators of commercial

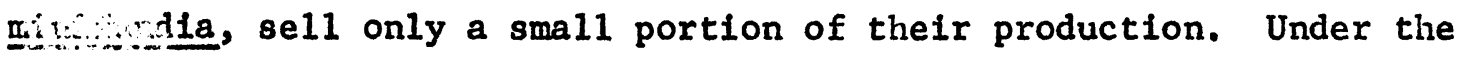
circuristances, there would be little opportunity for a cooperative to help procisers benefit from bulk sales, grading, or lower transportation costs. The opportunities are even less promising for a consumer cooperative to conno:e with the low margins charged by the large number of local merchants in the area. There appear to be few marketing functions which the cooperative could improve upon for this group of people.

Another alternative solution proposed by the Colombian Agrarian Reform Law of 1961 is to place a minimun size of six hectares on the land parcels which can be sub-divided. This, of course, if followed, may help prevent the formation of new minifundia units especially in areas of independent minifundia, but cannot treat the problems at hand in Sopo. This type of approach treats the results rather than the causes of the problem.

Still another solution for the minifundia has been widely discussed in Colombia. That is, the acceleration of the migration process so that occupants of the so-called marginal or minifundia units can be moved out of the rural areas. $17 /$ In some parts of Colombia this out-migration process is well advanced. Some of this shifting population, however, is moving into other rural areas. The continuing colonization thrusts, and the settlement in villages near large cities are important aspects of this process. Sopo falls into the latter case with respect to migration. That is, farm laborers continue to move into Sopo from more remote areas, while many of the young, healthy, aggressive, better educated individuals from the area move into Bogota. In large measure, the remaining occupants of the small farms in Sopo would be unable, within reasonable limits, to make the transition into the large city. Many of the operators of these small units who live in the rural area are not functionally literate, are of an age where new skills are almost impossible to learn, or enjoy sub-normal health. If these people moved to the cities they would only add to the social problems present there, 
and it is likely that their economic productivity would be lower than in their present activities. A number of the minifundia operators in Sopo are already closely identified with the urban environment through their occupations in the local village. It is doubtful if many of these would consider leaving the area. Taking a longer range view, however, it is likely that a substantial improvement in the level of rural education in Sopo would result in increased out-migration of the children, and thus some long term reduction in the number of small farm units if the immigration was also stanched.

Another major alternative for solution of the minifundia problems in Sopo relates to obtaining access to more land for the occupants of the small units identified as mixed or tied to large haciendas. This could include direct measures such as expropriation-parcelization, commercial parcelization, or inducing large landowners to rent more land to these individuals. Indirect measures which increase land taxes and labor costs may also be a means of encouraging the landowners to sell their lands or rent them out. Although a number of these minifundia operators could profitably utilize more land, there are also a number who could not because of their age, experience, or occupations. Approximately 100 of the operators of minifundia in Sopo might be candidates for utilizing more land under some special program. $18 /$ Substantial quantities of credit and technical assistance would be necessary, along with the land, to assure some measure of success to the new land operators.

\section{Summary}

Although we have far from exhausted the description of the small farm units in Latin America and the remedial alternatives which might be applied, the foregoing discussion should suggest the complexity of the problems faced in trying to treat minifundia. It should also indicate why agrarian reformers have had difficulty in applying the European experience with minifundia to Latin America. We argue that minifundia in Latin America are seldom a homogenous group which can be simply treated, and that some subclassification can be useful in evaluating remedial alternatives. At least in the Colombian case, we feel that grouping minifundia into the independent, various forms of dependent, and commercial types can help in establishing guidelines for problem solution. We attempted to show, through our discussion 
of the various forms of dependent minifundia in Sopo, how the different kinds of minifundia were formed, how the basic characteristics of these small units vary widely, and how a few of the commonly suggested remedial techniques relate to these units.

Given the type of minifundia present in Sopo and the diversity found among these units it is apparent that a bundle of techniques must be applied to treat the problems at hand. It is doubtful, for example, that many of the sma11 rural landowners who live in the local village, or who work in the village, can be drawn into full time farming positions. They would probably benefit more from programs which developed local industries, artesinal activities, or marketing services. A few of the tenant workers on the large farms could probably be helped to achieve landownership status through parcelization programs backed up by supervision and credit. Some of the other small farm operators in the area could also profit by such measures. It might also be possible for some of the tenant workers to exploit several of the large units in the valley through cooperative action. $19 /$ The remainder of the tenant workers could be assisted through enforcement of the national labor code which would raise their overall earnings. Still other operators of small farms in Sopo could be helped by the further development of home industries and off-farm opportunities for work.

Finally, it should be recognized that some of the operators of these small units cannot be substantially helped with any of the techniques presently being used by agrarian reformers. In these cases, programs must be developed to provide their children with better health and education so that their socio-economic opportunities can be extended beyond that of the parents. This ties in closely with the need for long term planning for minifundia. Not only do we need to correct existing problems, but we also need to project plans in this regard so that the undesirable conditions which occur in minifundia can be eliminated over time. 
Footnotes

* This paper results from joint research carried out by the Land Tenure Center, University of Wisconsin, and the Centro Interamericano de Reforma Agraria. The first sponsored by the Agency for International Development, and the latter a special program of the Organization of American States. The views herein expressed do not necessarily reflect those of the supporting Agencies.

1 / The most commonly suggested solutions for minifundia problems, drawing from the European experience, include parcel consolidation, laws which prohibit sub-division of small parcels, and out-migration programs.

2/ One hectare equals 2.47 acres.

3 / Departamento Administrativo Naciona1 de Estadistica (DANE), Directorio Nacional de Explotaciones Agropecuarias (Censo Agropecuario) 1960, Resumen Nacional (Segunda Parte), (Bogota: Multilith Estadinal, 1964), p. 39 .

4 / For another three way classification of minifundia see: Thomas F. Carrol1, "Reflexiones sobre la Distribucion del Ingeso y la Inversion Agricola," Temas de1 BID, Ano 1 No. 2, August 1964, p. 33. His classification is briefly: (1) those small units which could be viable with some additional land, (2) those units which could be viable with some other key input, and (3) those small units which cannot be made viable with their present resource base.

5 / For descriptions of several independent minifundia areas see: L. E. Montero and D. W Adams, Algunas Consideraciones sobre Reforma Agraria en Regiones de Minifundio: Un Ejemplo Colombiano (Bogota: IICA-CIRA, 1965); and A. Pearse and S. Rivera, Tenza, Boyaca: Un Estudio de un Area de Minifundio, Estudio Tecnico No. 4 (Bogota: Facultad de Sociologia, Universidad Nacional, 1967).

6 / For examples of commercial minifundia see: A. E. Havens, Tamesis: Estructura y Cambio (Bogota: Tercer Mundo, 1966); D. W Adams and L. E. Montero, "Land Parcelization in Agrarian Reform: A Colombian Example" Inter-American Economic Affairs Vol. 19, No. 3, Winter 1965; and D. W Adams et.al, Supervised Credit in Colombia's Agrarian Re form: An Evaluative Study (Bogota: IICA-CIRA, 1966).

I/ See A. E. Havens et.alo, Cerete Un Area de Latifundio: Estudio Economico y Social, Informe Tecnico No. 3 (Bogota: Facultad de Sociologia, Universidad Nacional, 1965), for an example of this type of dependent minifundia.

8/ See Orlando Fals Borda, Peasant Society in The Colombian Andes: A Sociological Study of Saucio (Gainesville, University of Florida Press, 1955); and A. Pearse, Factores Sociales que Inciden en el Desarrollo Economico de La Hoya del Rio Subachoque (Bogota: Facultad de Sociologia, Universidad Nacional, 1963), for two studies done in areas with mixed dependent minifundia. 
9/ Enrique Ortega Ricaurte, San Salvador de Sopo (Bogota: Imprenta Nacional, 1935), p. 32.

10/ Guillermo Hernandez Rodriguez, De Los Chibchas a la Colonia y a la Republica (Bogota: Seccion de Extension Cultural, Universidad Nacional de Colombia, 1949), p. 184.

11/ Ortega Ricaurte, op. cit., p. 65 .

12/ Ibid, pp. 14-17.

13/ The population data cited in this section came from the 1938, 1951 and 1964 Population Census of Colombia.

14/ Censo Agropecuario, op. cit.

15/ A similar conclusion for most of Colombia was reached in another study: Carlos de Soroa y Plana, Estudio del Minifundio en Colombia Desde el Punto de Vista de Las Posibilidades de Realizacion de La "Concentracion Parcelaria" (Bogota: Dept. of Tech. Studies, INCORA, 1964), p. 37.

16/ For a further exposition of the aims of supervised credit see: $D$. $W$ Adams, et.al., op. cit., pp. 7-8.

17/ This alternative is strongly argued by Lauchlin Currie in, Accelerating Development: The Necessity and The Means (New York: McGrai-Hill, 1966).

18/ It should be noted that the Colombian Institute for Agrarian Reform's (INCORA) ability to obtain land for parcelization in an area like Sopo is sharply limited. Under present law it is doubtful if any of the large units in Sopo could be expropriated by INCORA. Some sort of commercial purchase would probably be necessary in this case before land could be obtained for parcelization.

$19 /$ For a discussion of this system of exploitation see: Peter Dorner and J. C. Collarte, "Land Reform in Chile: Proposal for an Institutional Innovation," Inter-American Economic Affairs, Vol. 19, No. 1, Summer 1965, Pp. 3-22. 